\title{
Reforms of the higher education system in Poland since 1989. Between tradition and challenges of the 21 st century
}

\author{
Justyna Wojniak ${ }^{1}$, and Marta Majorek $^{2}$ \\ ${ }^{1}$ Pedagogical University of Krakow, Podchorążych 2, 30-084 Kraków, Poland \\ ${ }^{2}$ Andrzej Frycz Modrzewski Krakow University, Herlinga - Grudzińskiego 1, Kraków 30-705, Poland
}

\begin{abstract}
The paper discusses changes within the academia in the context of political, social and economic transformation of 1989 in Poland. The considerations are based on the views and aims of higher education reflected in the university reforms that were undertaken between 1990 and 2018. The study is focused on political background of the reform concepts and on the regulations that were introduced, as well as on the contemporary trends shaping the education processes. The authors attempt to answer the question concerning the influence of Polish transformation process on the traditional mission of the university and its specific social and cultural role. Keywords. Higher education, education system reform, university, Poland
\end{abstract}

\section{Introduction}

The period of political system's transformation in Poland that was in general initiated by the changes of 1989, raised plenty of new, difficult, and sometimes unknown problems to solve. Not only politicians had to face them, but the whole society as well. Even the main animators of these events did not have a clear vision of social, economic and cultural transformations. Fundamentally, the principles of democracy, market economy and pluralism in socio-cultural life were employed to define the direction of future changes. In principle, no politician or expert was able to fully sketch out a scenario of the upcoming events or provide any approximate dates for solving the great social issues. The phenomenon of unemployment as well as the public finance crisis intensified with great force. This has affected all sectors and areas of economic and socio-cultural life, without any exception. It is obvious that the educational system of the Republic of Poland could not stay off the beaten track of these changes. The tradition of Polish educational reforms is that they have always been undertaken and implemented in the difficult and crucial moments of our history[1].

The idea of changing the Polish educational system was based on three crucial elements:

- decentralization (as mentioned, 1989 marked the end of the monopoly of the government in shaping education system);

- democratization (both in the context of the management system and the vision of educational ideals that promote pluralistic thinking);

- utilitarianism (the use of education for development of creative and flexible personalities of young people who possess knowledge consistent with the highest expectations) [2].

\section{Transformation of higher education system in Poland}

One of the most serious repercussions of changes that took place in 1989 was Poland's transition from an exclusive higher education system to its mass stage. This process implies phenomena of a positive nature, such as an increase in the number of universities and attending students, as well as the negative ones: the main example is a noticeable drop in the quality of education or maladjustment of the educational offer to the requirements of the labor market [3].

The expectations regarding potential benefits of participation in higher education have also been transformed. The development impulses provided by the political transformation (opening to global influences, a new system of social structures or even the necessity to revise the current directions of economic development) made 1989 the turning point for educational institutions. Undoubtedly, further changes in the

\footnotetext{
${ }^{1}$ Corresponding author: justyna.wojniak@up.krakow.pl
} 
school system would not be so rapid and profound without such a radical transformation of the political system [4]. Under the pressure of the growing expectations of the young generation concerning the level of education, the government made attempts to reform higher education. The most crucial in this matter (mainly due to the fact that the university was liberated from the current political supervision) were two legal acts from 1990 which were the aftermath of the reform of science and higher education, adopted by the government of Tadeusz Mazowiecki [5].

These laws constituted the basis for further changes in the functioning of universities and, later, their visible diversification. The Act of 1990 provided the division of the university only into public and private. It was only the Act on Higher Vocational Schools [6] that introduced differentiation into private institutions operating under the Act of 1990 and private vocational schools. However, that fact is that the visions of change put forth by successive governments have not always been reflected in reality. It may currently suggest that work on modifying higher education was chaotic and internally incoherent [7].

\section{Modernization of higher education - from elitism to mass education}

After the implementation of the Act of 1990, higher education in Poland entered a period of educational boom: an unexpected eruption of universities (thanks to the law - especially non-public schools), and a sharp increase in enrollment rate at the university level. However, the development of the higher education sector was chaotic, and the dissemination of higher education did not go hand in hand with care for its quality [8].

The unprecedented increase in the number of students which has occurred since the beginning of the $90 \mathrm{~s}$ is not only the effect of a baby boom from the seventies, but a component of numerous factors, including:

- increasing awareness of the value (or even the necessity) of education and the associated social pressure exerted, in particular, on younger generations;

- the constantly increasing number of places in colleges. It was an effect of the state policy, according to which the amount of public funds transferred to the university depended on the number of enrolled students;

- at the beginning of the transformation period the changes in the employment model resulting for the increased demand for employees with higher education diplomas, later - the willingness to postpone the moment of entering into adulthood- the result of significant problems in the labor market;

- abolition of the need to pass university entrance exams;

- an increase in civic awareness and improvement of democratic culture [9].

In addition, with the signing of the Bologna Declaration in 1999, the necessity to face the challenges of the European Union's education policy embodied by the Bologna Process [10]. The accession of Poland to the European Union in 2004 also meant joining the process of implementing the postulates of the Lisbon Strategy, in which, among others, education and human rights were recognized as the key to the socio-economic development of the Union [11].

Modernization of the higher education system has thus become one of the priorities of European education policy, as evidenced by a number of European Commission documents emphasizing the role of higher education in the implementation of this multiannual European reform program and structural changes. For this reason, after fifteen years of socio-economic changes in Europe and in Poland, the Higher Education Act of 1990 turned out to be understandably incompatible with contemporary conditions [12].

Another reform was introduced by the Law on Higher Education of 27 July 2005. It shaped both the external academic order and some elements of the internal order; it also defined the principles of organization and operation of higher education institutions, the mode of their creation and liquidation, competences of academic teachers and other university employees, as well as the competences of institutions such as the Polish Accreditation Commission or Main Council of Science and Higher Education [13].

The law on higher education from the 2005 was the result of arrangements among rectors of public and nonpublic universities, but also among trade unions, the Students' Parliament and various councils (Main Council of Higher Education, Polish Accreditation Commission), but many noticed that it did not bring any significant changes. The most visible ones concerned:

- introduction of a three-level division of studies (for undergraduate, graduate and doctoral programs),

- the need to conclude contracts between students and universities at paid studies,

- introduction of the principle that the new secondary school-leaving examination is the basis for admission to universities,

- continuation of the current, traditional type of a scientific career (keeping habilitation),

- limitations on the multi-subject nature of research and teaching staff,

- stating that the rectors of non-public universities can be people with lower academic qualifications than those of public universities (a doctor's degree is enough),

- allowing a rector to be dismissed by the minister in case of gross violation of law, and in case of significant violation of law (or statute),

- obligation to initiate explanatory proceedings in case of suspicion of plagiarism in diploma thesis, 
- suspension of the title / degree awarding procedure; in the case of suspicions of plagiarism, corruption, paid protection or other scientific fraud, instituting disciplinary proceedings [14].

Despite appreciating the fact that the new law tidied up higher education legislation, adapting it to the requirements of the Bologna Declaration and the changed socio-economic situation of the country, it has been criticized by many representatives of the academic community. It was accused of responding only to the existing needs reported by the environment, but not going further into the future with its perspective - so it will not contribute to the competitiveness of the Polish economy. It has been pointed out that maintaining the discrepancies between legal provisions and educational reality causes numerous negative consequences, including encouraging the simulation of actions enforced by law. [15].

However, some of the opinions and comments indicated that the introduced changes also have a positive aspect. One of the examples is Article 4 of the Act which is devoted to the autonomy of universities - that is a perfect example of properly conducted deregulation [16].

It is clear that the Law on Higher Education of 2005 pointed out a number of errors and shortcomings quite quickly. In response to the criticism, the government, at the end of the first decade of the 21st century, prepared a package (in principle) of radical changes and subjected it to public discussion. For the first time after 1989, some new higher education stakeholders - not just the academic staff and its representatives - were clearly identified and asked about official views on the reform package. These views, as it turned out, were significantly different from the views of the academic community. The group of stakeholders was involved in the long process of social consultations which included students in particular - and indirectly their parents, PhD students and their organizations, as well as employers through their associations.

Seeking for supporters, the reformers from 2009-2011 turned directly to the new stakeholder groups and showed a possible outcome of the long-term reforms. The opposition of the academic community to the main parts of the reform package was accompanied by relatively large support from these new stakeholders. Further official "reform assumptions" presented in various forms in 2009-2010 emphasized the instrumental nature of the expected changes and marked the end of the domination of the traditional university perception. It was no longer an isolated community of researchers and the end of the traditional symbiosis between political decisionmakers and the rectors of public universities. The reforms were the first response to the structural problems that had been accumulating over two decades. The institutional autonomy and institutional democracy recovered in 1990, expressed in the extreme, extended academic collegia, meant that systematic transformation of the university (e.g. coordination of market-based (or quasi-market) areas of part-time studies or rationalization of university expenses) became impossible for numerous years. Extreme democratic forms of management also made it more and more difficult to periodically assess the quality of institutionally and individually conducted research. At the same time - and this had a huge negative and demotivating effect on the entire academic profession - it was impossible to dispose of the weak academic staff, unable to meet even the basic requirements of the research mission. The response of the reformers from 2009-2011 to the above structural problems is, on the one hand, the creation of the Scientific Units Evaluation Committee (KEJN), and on the other - the National Science Center (NCN). However, after several years of functioning of those institutions their limitations became apparent: powerlessness of parameterization and categorization in fulfilling the task of raising the quality of scientific research [17] and underfunding the most important funding institution for research (accompanied by a decrease in statutory research expenditure).

The changes that came into force at the beginning of the academic year 2011/2012 included, among other things, creation of a pro-quality fund, as well as rules for starting novel study programs ( universities gained more freedom in this respect). The reform introduced the payment for studies in the second course (students who achieve the best results have been released from the payment) and the obligation to conclude a contract between the university and the student, regulating, among others, range of fees [18].

However, the problem of selecting and promoting research universities was not solved, and more broadly the lack of vertical stratification in the system still remained. The reform of the system of academic degrees and the promotion system also failed - the average level of habilitation and titular professorship has dropped significantly, and there was no forecasted increase in the internationalization of scientific research. Participation of Poland in the European Research Council (ERC) grant system turned out to be a disaster. Pressure on subsequent reforms was inevitably growing, especially in the face of a direct confrontation of thousands of Polish researchers with Western systems and growing internationalization of Polish science [19].

\section{4 "Constitution for Science" - A comprehensive reform or a risky experiment?}

According to the European Commission data, Poland has achieved the main goal of the Europe 2020 strategy, which refers to the percentage of people with higher education - in 2016, this rate was $44.6 \%$ and was higher than the EU average of $39.1 \%$. Thus, Poland turned out to be a country that has one of the highest rates of citizens with higher education in the entire EU, and it seems that the national target of $45 \%$ will be achieved without major obstacles by 2020. [20] 
Although in recent years Poland has recorded a steady increase in the employment of university graduates, among whom the employment rate of recent graduates is high and amounts to $87 \%$ compared to the EU average, which is $82.8 \%$ [21], there is the question of encouraging students to choose the fields of study for which there is the greatest demand for the Polish economy. This applies to pure sciences, technology, engineering and mathematics (STEM) and computer science. Therefore, the concept of reforms was one of the objectives that indicated the adjustment of higher education to future needs of the labor market. The need for changes in higher education also resulted from the need to consider the diverse level of students' abilities, interests and expectations.

A more in-depth analysis of the situation in Polish higher education led to identification of the most important areas requiring intervention. They included flawed rules regarding the organization and system of the university limiting the possibility of efficient management. The manifestation of this is the existence of extensive regulations describing, often in a meticulous way, management principles at the university level and their organizational units. Another element is the mismatch of the higher education system structure with social and economic challenges. Therefore, it was necessary to strengthen the professional universities on the one hand, focused on high-quality didactics, as part of practical studies, and on the other - to develop research universities that would be able to effectively compete with the best universities in Europe and around the world. The shape of the reform proposal was also influenced by the issue of limited financial autonomy of a university. This trend was manifested through several dozen streams of financing, based on separate rules regarding the possibilities and scope of spending funds [22].

Moreover, there are some doubts related to the unsatisfactory quality of education at universities, which was indicated by the insufficient adjustment of education to the needs of the socio-economic environment and low status of teaching staff. The problem of the quality of education also referred to $\mathrm{PhD}$ students. In their case, low effectiveness of education was pointed out, which was confirmed by the fact of a significant increase in the number of third-degree students which was not reflected in an increase in the number of persons who obtained a doctoral degree. In turn, in the case of academic staff, attention was paid to a system of degrees and titles, which acts as a brake on the researchers' pursuit of scientific excellence and conducting interdisciplinary research. The latter was not conducive to the fragmented classification of areas of knowledge, fields of science and art as well as scientific and artistic disciplines, linked to the qualifications to conduct higher education and doctoral studies, and to award degrees in science and art. The late age of obtaining scientific independence (postdoctoral degree) - 46 years - was also considered a significant problem of Polish science. Furthermore, it stressed a low level of global scientific research results in Poland, which is confirmed by the fact that publications of Polish scientists in $1 \%$ of the best sources of indexed international databases constitute only $0.7 \%$ [23].

Works on the statute were undertaken in February 2016, and their effects were presented in September 2017 at the National Congress of Science in Kraków. The new Polish strategy for science and higher education announced by the Ministry of Science and Higher Education is based on three pillars: "Constitution for Science", covering systemic changes in higher education, including its management and financing, "Innovations for the Economy", related to marketization scientific activity and cooperation with entrepreneurs and the "Science for You" program, supporting the social responsibility of science and its dissemination in the society [24].

What is important is that the entire academic and scientific community was invited to contribute to the reform. 15 expert teams from all over Poland took part in the competition for the assumptions to the Law on Higher Education, and the best three projects were selected by a competition committee consisting of scientists, educators, experts and entrepreneurs from the whole Poland. The Act consolidates the basic regulations in the field of higher education and science, integrating regulations in the scope that in the current legal state resulted from the Act on Higher Education, the rules of financing science, loans and student loans, academic degrees and academic title, and degrees and title in the field of art [25].

Most of the provisions of the statute will come into force on 1 October 12019 , but the first regulations were enforced in August 2018, and the process of full implementation of the act will be finished by 2022. The changes will take place in plenty of key areas of university functioning [26] - including, among others, the university system in the context of its autonomy. The purpose of the reform is to extend the autonomy of the university and increase flexibility in its organizational shape to eliminate the structure based on the "loose federation of faculties". Organizational principles on the basis of which the university is supposed to act will be included in the statute, considered as a superior document, while the statutory provisions will be limited to a minimum extent - the act regulates only the organizational form of the central university bodies). As for financial issues, the Act assumes that a university will receive one subsidy, which will be replaced by various targeted subsidies. The use of these funds is the subject of an individual decision of the university, depending on its needs. The Act also introduces a new, previously existing advisory body in the form of a university council, which also includes people from outside the academic community.

The new regulations also include wage increases for academic teachers and an increase in the level of employment stability - the second contract of employment will have to be concluded for an indefinite period. 
Only in the case of the first employment relationship, the candidate will be obliged to take part in the competition for the position of an academic teacher. The Act also introduces doctoral schools which will be run by universities and scientific institutes. The adoption of such a concept is associated with the desire to create an elite and pro-quality model of doctoral education in Poland. Studies with a practical profile will include at least 6 months of student internships.

Changes in higher education also apply to students and relate to such issues as: transparent information about studying fees at the time of study, decisions on the regulations of studies and the allocation of scholarships made in consultation with students or membership of student representatives in collegiate bodies of the university.

On 1 June 2019, the newly appointed Scientific Excellence Council (Rada Doskonałości Naukowej) started its term of office. The role of this body is to undertake activities for the development of scientific staff. It is connected with the care for the highest quality standards of scientific activity, the fulfillment of which is required to obtain academic degrees, degrees in the field of art and the title of a professor. The commencement of the council's activity is related to the next implementation stage of the "Constitution for science", which also includes the reform of the scientific promotion system. Ultimately, DAM will replace the Central Commission for Degrees and Titles in the supervision of individual promotion proceedings. The composition of the Council, which will include three representatives of each discipline will be determined by means of elections, in which all persons holding the postdoctoral degree, or the title of professor can participate [27].

Changes in regulations concerning the functioning of Polish higher education are also related to the introduction of differentiation into several types of universities. We therefore deal with regional universities, public vocational colleges and research universities. The first are located in smaller academic centers, the second ones specialize in practical education, and the last ones will be the leading research centers in the country that can compete with foreign universities. A separate financial algorithm is provided for each category, taking into account the specificity of their operation [28].

The proposed draft of reforms have caused a number of controversies and have been criticized not only by representatives of the academic community but also by some of the politicians of the ruling party. The doubts and protests concerned mostly the power of university councils, such as nominating candidates for rectors or establishing university strategies, which was considered an attempt to limit academic autonomy. The idea to hand over too much power to the one-man university body, which is the Rector, was also strongly criticized. It was about competence in determining the organizational structure of the university, creating faculties and appointing deans. The separation of research and regional universities, in turn, was considered a step towards deepening inequalities between smaller regional universities and large universities in big cities [29].

Objections regarding the content of the new regulations were also expressed by the institution established to support the scientific advice of the legislative process, which is the Office for Parliamentary Analysis [30]. In the opinion of 30 April 2018, it was pointed out that the statute is a compilation of new regulations, replacing repealed laws, which makes it not clear, and it is not conducive to the transparency of the legal system concerning higher education. A serious drawback was also the fact that the project is an attempt to adopt the system solutions of other countries where higher public and private funds are allocated to financing higher education. The author doubts whether this type of model is possible to implement in Poland.

Furthermore, the cited opinion indicated that the establishment of university councils will result in the transfer of public funds earmarked in the budget for education to those bodies that will not engage in research activities. In the face of limited and insufficient expenditure on science, their further limitation by allocating funds for financing bodies that will not conduct research should be assessed as contradictory to the assumptions of the bill. Restricting the decision-making capabilities of collegiate bodies only to a centrist position of the rector, who obtains actual power in a higher school, was also criticized. In this way, the rights of collegial bodies of higher education institutions, above all the senate and individual faculty councils, will be significantly reduced. In the latter case, faculties and their managers - deans - become bodies that are directly dependent from the rector. In practice, the transfer of decision-making powers to the rector will mean the squaring of the hitherto organizational achievements of Polish higher education, in particular the role of faculties. It is also a threat to the internal autonomy of public higher education institutions because it is the individual faculty councils - as collegial bodies, traditionally forming an academic community - that represent the interests of particular branches of science and this is where real didactic and scientific work takes place [31].

\section{Conclusion}

Reforms of the higher education system in Poland are undoubtedly a part of global changes, the element of which is the evolution of the relationship between the state and the academy. Renegotiations of these relations can be observed in Western Europe over the last three decades [32]. This is due to the fact that the majority of developed European economies are increasingly based on knowledge. Hence, the emphasis on far-reaching university reforms as an institution and, understandably, the entire higher education system, is becoming more and more visible. At the same time, knowledge, including academic knowledge, becomes the point which the 
issues of development of contemporary societies are focused on. The changing social, economic, cultural and legal environment of European higher education institutions more often forces them to function in a state of permanent adaptation to changes in financing and management. This also applies to Poland [33]. The shift in thinking about the policy of higher education, which took place in Poland, clearly shows a new direction of change - known from Western European systems departing from the model of Humboldt's "republic of scholars" towards a model where the role of the external environment of the university is radically increasing [34]. An illustration of this tendency is the quoted opinion of the Office for Parliamentary Analysis, whose vision, close to the concept of the "republic of scholars", clashes with the vision represented by the project of the Ministry of Science and Higher Education.

Regardless of these disputes, one of the most important problems of a modern university is depersonalization and an approach where a man is not important and what matters are the transfer, product, commercialization, effects and profits. In such a system there is no chance to build a master-student relationshi, because nonuniversity factors such as donors, including business, are becoming more and more important. It is also not conducive to new teaching methods, which more closely resemble coaching and training methods and, as a result, lead to a university change in the master's factory meeting certain quality standards. What happens in the academic environment can be explained by the collision of academic and corporate culture. The fiscalization of science observed today also results in the dependence of the environment on external factors, and the economic status of scientists and trends aiming at commercialization of research results may create the temptation to compete for the priority of results at the expense of their reliability. This trend can be extremely worrying if we take into account the relatively low financial outlays that are earmarked for science in Poland.

Undoubtedly, it is worth referring to the changing context of the university's functioning and, consequently, it is difficult to disagree with the necessity of "renegotiating the social contract of the state with the academy" [35]. However, the redefinition of the academy should be understood in terms of rebuilding and renaissance. This does not mean, therefore, rejecting the "old" rules. Regardless of how far we move away from the university concept as a "republic of scholars", we cannot reject the ethos of science. It is worth referring here to the values mentioned, among others, by Robert Merton, who introduces four sets of institutional ethics of modern science: communism, universalism, disinterestedness, and organized skepticism [36].

\section{References}

1. S. Majewski, Przemiany oświaty $i$ wychowania w Polsce w latach 1989-1995, Studia Pedagogiczne. Problemy Społeczne, Edukacyjne i Artystyczne" 11, pp. 189-214 (1996)

2. M. Raczyńska, Od elitarności do masowości. Stan szkolnictwa wyższego w Polsce po transformacji ustrojowej z 1989 r., Poliar. 1, p. 222, (2013)

3. Ibid.

4. M. Niezgoda, Społeczne skutki zmiany oświatowej w Polsce. WUJ: Kraków, p. 11, (2011)

5. Act of 12 September 1990 on higher education, OJ 1990 No. 65 item 385, (1990), Available at: http://prawo.sejm.gov.pl/isap.nsf/DocDetails.xsp?id=WDU19900650385

6. Act of June 26, 1997 on Higher Vocational Schools, Available at: http://prawo.sejm.gov.pl/ isap.nsf / download.xsp / WDU19970960590 / U / D19970590Lj.pdf

7. M. Raczyńska, Od elitarności do masowości. Stan szkolnictwa wyższego w Polsce po transformacji ustrojowej z 1989 r., Poliar. 1, p. 223, (2013)

8. A. Dziedziczak-Foltyn, O reformowaniu szkolnictwa wyższego w Polsce $w$ latach $1989-2009 i$ towarzyszacej temu debacie publicznej, p. 55, (2009). Available at: http://cejsh.icm.edu.pl/cejsh/element/bwmeta1.element.desklight-032b955a-0c49-4f2c-8088bbe5265cf0da

9. M. Raczyńska, Od elitarności do masowości. Stan szkolnictwa wyższego w Polsce po transformacji ustrojowej z 1989 r., Poliar. 1, p. 225, (2013)

10. A. Kraśniewski, Proces Boloński. To już 10 lat. Warszawa, (2009). Available at: http://czytelnia.frse.org.pl/media/proces_bolonski_FINAL.pdf

11. L. Pepin, Education in the Lisbon Strategy: assessment and prospects, Ac. Jour. Dev. and Pol., 46, issue 1, (2011), Available at: https://doi.org/10.1111/j.1465-3435.2010.01459 .x

12. A. Dziedziczak-Foltyn, O reformowaniu szkolnictwa wyższego w Polsce $w$ latach 1989-2009 $i$ towarzyszacej temu debacie publicznej, p. 57, (2009). Available at: http://cejsh.icm.edu.pl/cejsh/element/bwmeta1 .element.desklight-032b955a-0c49-4f2c-8088bbe5265cf0da

13. M. Raczyńska, Od elitarności do masowości. Stan szkolnictwa wyższego w Polsce po transformacji ustrojowej z 1989 r., Poliar. 1, p. 225, (2013) 
14. Act of Higher Education Law (2005). Available at: http://prawo.sejm.gov.pl/isap.nsf/download.xsp /WDU20051641365/U/D20051365Lj.pdf

15. M. Wójcicka, Zmiany w szkolnictwie wyższym z procesem bolońskim $w$ tle, Przeg. Socjol. 58, 3, p.22, (2009)

16. J. Woźnicki, Postulat selektywnego charakteru deregulacji w szkolnictwie wyższym, Na. i Szkol. Wy. 2, 50, p. 99, (2017)

17. Narodowe Centrum Nauki pod ostrzatem krytyki. Realizacja projektów naukowych utrudniona, Gazeta prawna (2018), Available at: https://serwisy.gazetaprawna.pl/edukacja/artykuly/1293889, narodowe-centrum-nauki-utrudnirealizacje-badan.html

18. M. Dybas, A. Dziemianowicz-Bąk, M. Krawczyk-Radwan, D. Walczak, Continuation of Change Report on the State of Education 2011, Warsaw, p. 24, (2012). Available at: http://produkty.ibe.edu.pl/index.php?id=28.

19. M. Kwiek, Wprowadzenie: Reforma szkolnictwa wyższego w Polsce i jej wyzwania. Jak stopniowa dehermetyzacja systemu prowadzi do jego stratyfikacji, Na. i Szkol. Wy. 2, 50, p. 14, (2017)

20. Monitor edukacji i kształcenia 2017. Polska, European Commission, p. 8., (2017)

21. Dane statystyczne dotyczace zatrudnienia, Eurostat, (2019). Available at: https://ec.europa.eu/eurostat/statistics-explained/index.php/Employment_statistics/pl .

22. Reformy krajowe $w$ zakresie studiów wyższych. Polska. Eurydice, (2019). Available at: https://eacea.ec.europa.eu/national-policies/eurydice/content/national-reforms-higher-education $50 \_\mathrm{pl}$

23. Ibid.

24. Ponad rok przygotowań, Ministerstwo Nauki i Szkolnictwa Wyższego (Ministry of Science and Higher Education), (2019). Available at: https://konstytucjadlanauki.gov.pl/prace-nad-reforma

25. Doskonalimy polska naukę. Ministerstwo Nauki i Szkolnictwa Wyższego (Ministry of Science and Higher Education), (2019). Available at: https://konstytucjadlanauki.gov.pl/podsumowanie-zmian

26. Reformy krajowe $w$ zakresie studiów wyższych. Polska. Eurydice, (2019). Available at: https://eacea.ec.europa.eu/national-policies/eurydice/content/national-reforms-higher-education $50 \_\mathrm{pl}$

27. Doskonalimy polska naukę. Ministerstwo Nauki i Szkolnictwa Wyższego (Ministry of Science and Higher Education), (2019). Available at: https://konstytucjadlanauki.gov.pl/podsumowanie-zmian

28. Nauka w Polsce (Science in Poland ).( 2019). Available at: http://naukawpolsce.pap.pl/aktualnosci/news\%2C30089\%2Cwiceminister-nauki-uczelnie-regionalnenie-straca-na-reformie .html

29. List otwarty w sprawie statutu, Komitet Kryzysowy Humanistyki Polskiej, (2019). Available at: http://kkhp.pl/wpisy-dokumenty/

30. Opinia merytoryczna i prawna o rządowym projekcie ustawy Prawo o szkolnictwie wyższym i nauce (druk $n r$ 2446) oraz o rzadowym projekcie ustawy Przepisy wprowadzajace ustawe Prawo o szkolnictwie wyższym i nauce (druk nr 2447), Biuro Analiz Sejmowych (Office for Parliamentary Analysis), (2018). Available at: http://www.sejm.gov.pl/Sejm8.nsf/opinieBAS.xsp?nr= 2446

31. Ibid.

32. M. Kwiek, Uniwersytet $w$ dobie przemian. Instytucje i kadra akademicka $w$ warunkach rosnacej konkurencji, Warszawa: Wyd. Naukowe PWN, pp. 23-24, (2015)

33. M. Kwiek, Wprowadzenie: Reforma szkolnictwa wyższego w Polsce i jej wyzwania. Jak stopniowa dehermetyzacja systemu prowadzi do jego stratyfikacji, Na. i Szkol. Wy. 2, 50, p. 10, (2017)

34. M. Kwiek, Changing Higher Education Policies: From the Deistitutionalization to the Reinstitutionalization of the Research Mission in Polish Universities, Sci. and Pub. Pol., 39, 5, p. 652, (2012)

35. M. Kwiek, Wprowadzenie: Reforma szkolnictwa wyższego w Polsce i jej wyzwania. Jak stopniowa dehermetyzacja systemu prowadzi do jego stratyfikacji, Na. i Szkol. Wy. 2, 50, p. 15, (2017)

36. R. K. Merton, Teoria socjologiczna i struktura społeczna, Warszawa: Wyd. Naukowe PWN, p. 581, (1982) 